Костюкевич А. М., к.е.н., Костюкевич Р. М., к.е.н., доцент

(Національний університет водного господарства та

природокористування, м. Рівне)

\title{
НАУКОВО-МЕТОДИЧНІ ПІДХОДИ ДО РОЗРОБЛЕННЯ МЕХАНІЗМУ ПІДТРИМКИ МОЛОДІЖНОГО ПІДПРИЕМНИЦТВА В УКРАЇНІ
}

Доведено потребу розроблення механізму підтримки молодіжного підприємництва в Україні. Удосконалено концептуальну модель механізму розвитку молодіжного підприємництва, що базується на SADT-методології, за допомогою якої аналізуються функції, що виконує система, описуються специфікації вимог і функцій проектованої системи та проектуються системи.

Ключові слова: підприємництво, молодіжне підприємництво, механізм підтримки підприємництва, SADT-методологія.

Вступ. Підприємницька активність $є$ основним фактором розвитку інноваційної економіки. Соціологічні дослідження свідчать, що молодь порівняно краще пристосована до підприємництва, прагне до фінансової свободи, позитивно ставиться до ринкових форм господарювання. Отже, стимулювання саме молодіжної підприємницької активності може стати суттєвою передумовою для розвитку інноваційної економіки в Україні.

Дослідження показали, що українська молодь має меншу схильність до підприємницької діяльності, ніж мешканці країн Західної Європи та інших розвинених країн [1]. Водночас українські стратегії та програми розвитку підприємництва не мають достатньо механізмів та інструментів підтримки молодіжного підприємництва та не інтегровані у навчально-виховний процес на рівні закладів середньої та вищої освіти.

Аналіз останніх досліджень. Тема молодіжного підприємництва ґрунтовно розглянута в наукових працях закордонних фахівців 3 молодіжних питань, таких як Г. Уільямсон, Р. Макдональд, Ф. Коффілд. Проблемами молоді та молодіжного підприємництва займаються ряд вітчизняних вчених, а саме Ю.О. Бєлкін, М.Ф. Головатий, В.А. Головенько, В.А. Гросул, І.Л. Демченко, О.М. Костенко, А.О. Левченко та інші.

Постановка завдання. На сьогодні існує недостатньо публікацій, які б акцентували увагу на висвітлення поняття та розвиток молодіжного підприємництва, його державну підтримку. Здебільшого ці 
питання розглядаються у контексті молодіжної політики у комплексі з питаннями дозвілля та стану здоров'я, політичної та громадської активності, сімейних цінностей та інше. Тому актуальним є обґрунтування науково-методичних засад запровадження механізму підтримки молодіжного підприємництва в Україні.

Наукові результати. Система розвитку молодіжного підприємництва потребує підтримки на різних рівнях економічної системи. Це обумовлено рядом факторів, що випливають із особливостей цього специфічного виду діяльності. Основними з них є:

- сфера молодіжного підприємництва охоплює молодь різного віку, серед яких є неповнолітні, що обмежує їх правоздатність, а тому потребує застосування спеціальних механізмів регулювання;

- молодіжне підприємництво розпочинається, переважно, в умовах відсутності досвіду команди (або незначного досвіду), що значно підвищує ризики такої діяльності та потребує застосування різних форм бізнес-інкубації і менторської підтримки;

- підприємці-початківці, як правило, не мають власних ресурсів для започаткування власної справи, тому для стимулювання такого виду діяльності потрібно розвивати мережу фінансової підтримки новостворених молодіжних бізнес-проектів.

Цілісний механізм підтримки молодіжного підприємництва може ефективно функціонувати і давати очікувані результати, якщо він забезпечуватиме одночасне дотримання таких умов:

- достатньо велика частина молоді мотивована, має бажання та схильність займатися підприємництвом;

- для осіб, що мають бажання займатися підприємництвом, створено можливості для набуття необхідних здатностей щодо організації та розвитку бізнесу;

- підприємці-початківці мають можливості залучати ресурси для заснування власної справи.

3 урахуванням наведених умов та особливостей можна побудувати концептуальну модель розвитку молодіжного підприємництва.

Для вирішення цього завдання ми застосуємо методологію SADT (Structured Analysis and Design Technique), що дозволяє побудувати модель системи та стандарт цієї методології IDEFO (Icam DEFinition, де Icam - це Integrated Computer Aided Manufacturing) [2], що є загальновизнаним підходом до опису функцій будь-якої організаційно-технічної чи організаційно-економічної системи.

Методологія SADT (створена на основі SASD методології) є однією із найвідоміших методологій аналізу і проектування систем. Її особливістю $€$ те, що вона моделює такі властивості систем як управління, зворотній зв'язок і ресурси. Автором SADT вважають Дугласа 
Росса, який у 1969 р. частину своїх теорій, що відносяться до методології й мови опису систем, назвав SADT (Structured Analysis and Design Technique). А вже у 1973 р. вона була застосована при розробці масштабного аерокосмічного проекту.

За допомогою SADT-методології вирішуються такі основні завдання (для систем будь-якого типу):

- аналіз функцій, виконуваних системою;

- опис специфікацій вимог і функцій проектованої системи;

- проектування системи.

Саме здатність виконувати наведені завдання спричинила вибір даного методу дослідження. При цьому ми обмежимося лише структурним моделюванням на рівні моделей вищих рівнів, що дасть змогу зрозуміти основні структурні елементи системи та їх взаємозв'язки, необхідні для отримання виходів системи, основними з яких на загальнодержавному рівні ми визначили:

- довгостроковий потенціал розвитку економіки;

- розвиток креативних індустрій з високою доданою вартістю;

- підвищення зайнятості молоді.

На основі наведеного побудовано концептуальну модель розвитку молодіжного підприємництва (див. рис. 1).

Для розуміння сутності механізму доцільно провести його декомпозицію у розрізі етапів та суб'єктів управління. Вважаємо, що для охоплення усіх етапів, механізм розвитку молодіжного підприємництва повинен охоплювати 4 підсистеми, об'єднані в єдиний цілісний механізм.

Для забезпечення належної візуалізації механізму у даному дослідженні ми змушені розділити його на частини (див. рис. 2-5), які умовно назвали:

- загальнодержавний рівень (частина 1);

- регіональний рівень (частина 2);

- освітня підсистема (частина 3);

- інфраструктурна підсистема (частина 4).

На загальнодержавному рівні (див. рис. 2) основна роль суб'єктів підтримки молодіжного підприємництва полягає у формуванні нормативно-правових засад та створення можливостей ресурсного забезпечення, що повинно випливати з державної політики розвитку молодіжного підприємництва. Така політика викладена у «Стратегії розвитку малого і середнього підприємництва в Україні на період до 2020 року» [3], де передбачена ціла система заходів із розвитку молодіжного підприємництва. Разом з тим, в Україні на сьогодні немає сформованої державної політики у сфері стимулювання соціального підприємництва. 


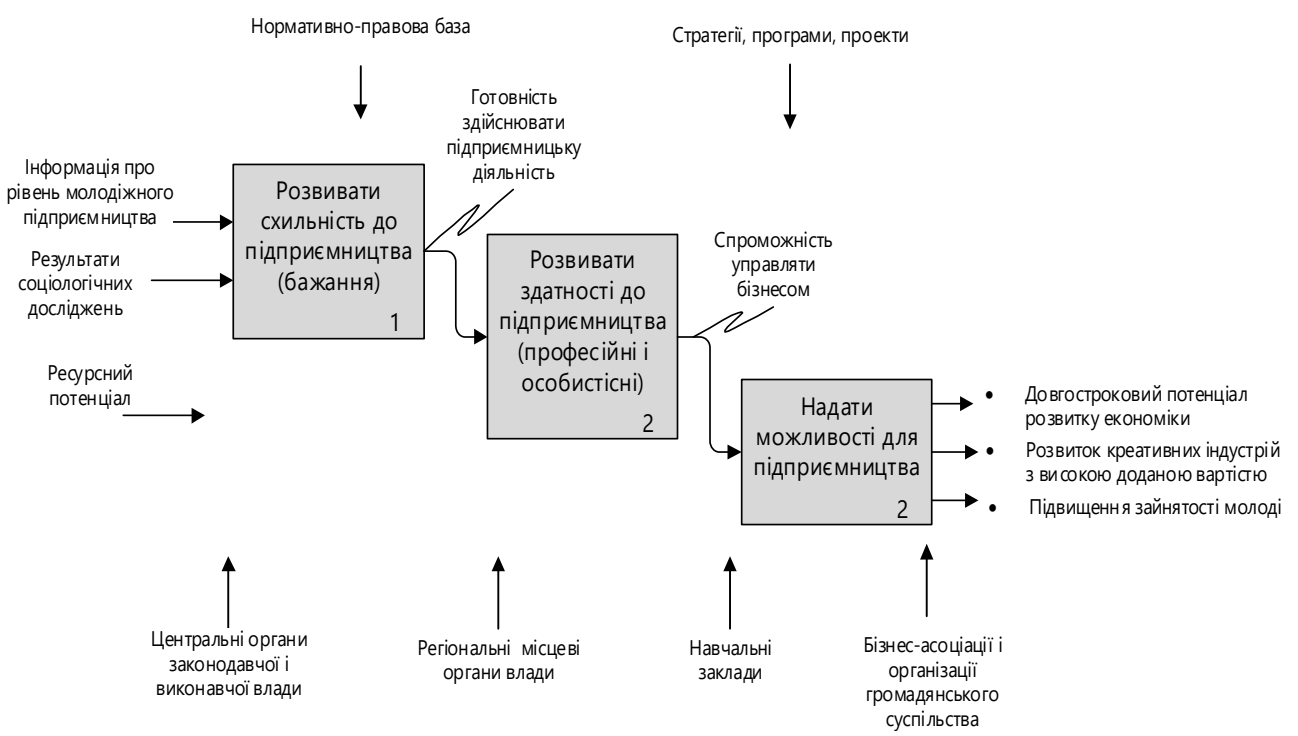

Окреме місце у цьому механізмі належить Міністерству освіти і науки України, яке повинно забезпечити передумови до підвищення схильності і бажання молоді займатися підприємництвом, шляхом внесення до стандартів освіти відповідних навчальних модулів на усіх рівнях освіти.

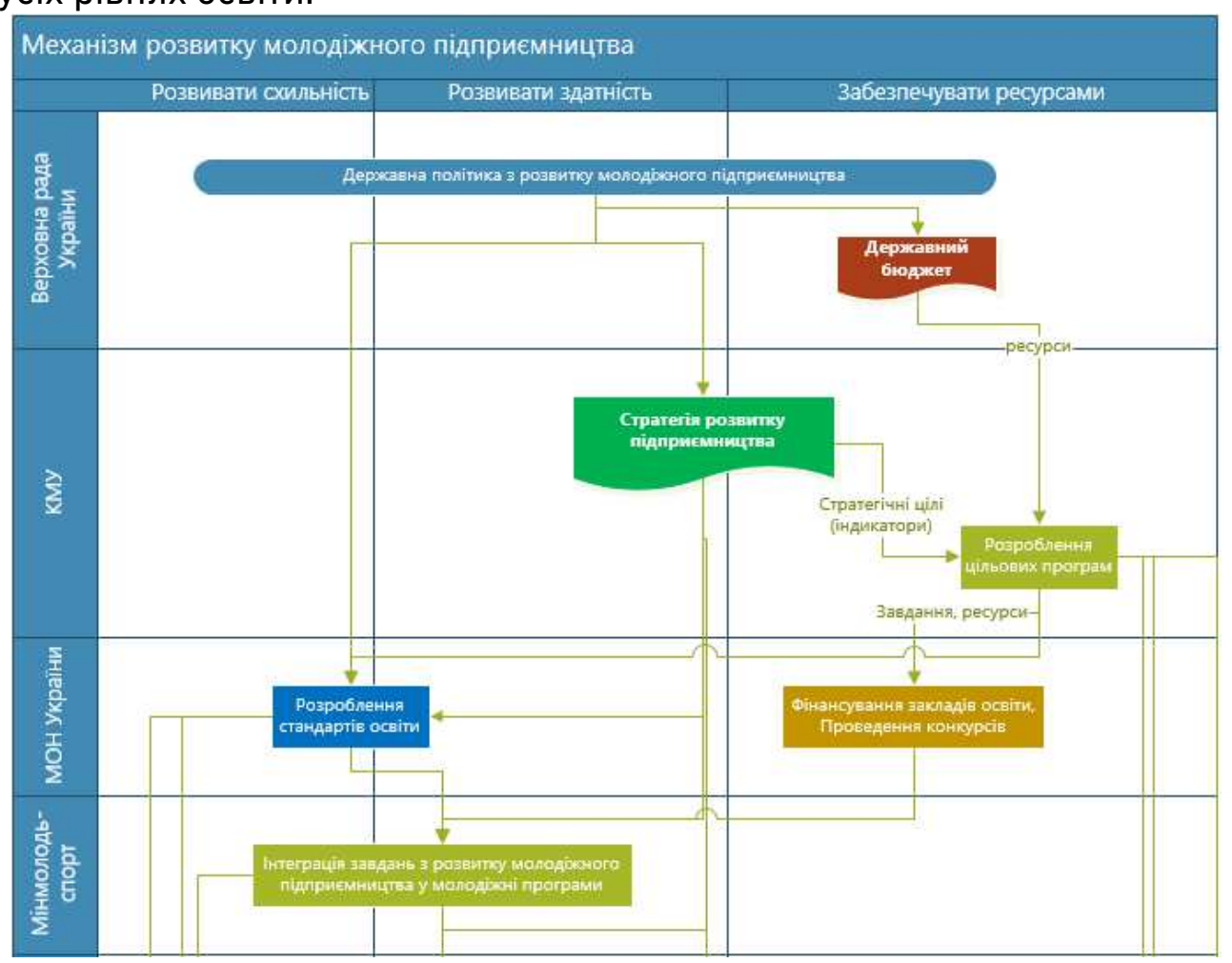

Рис. 2. Механізм розвитку молодіжного підприємництва (частина 1 - загальнодержавний рівень) 
Реалізація державної політики повинна відбуватися через механізми на регіональному і місцевому рівні. її механізм наведено на рис. 3.

Як видно з рис. 3 ефективність механізму залежить від дієвості програмно-цільового управління на регіональному і місцевому рівні, оскільки у разі успішної реалізації цілей регіональних і місцевих стратегій і програм буде формуватися підприємницька інфраструктура та реалізовуватися проекти, спрямовані на розвиток молодіжного підприємництва.

Схильність і здатність до підприємницької діяльності повинна формуватися за допомогою механізмів формальної і неформальної освіти (див. рис. 4), передумови якої закладаються, насамперед, на державному рівні через систему стандартів освіти та організації навчально-виховного процесу на різних рівнях освіти.

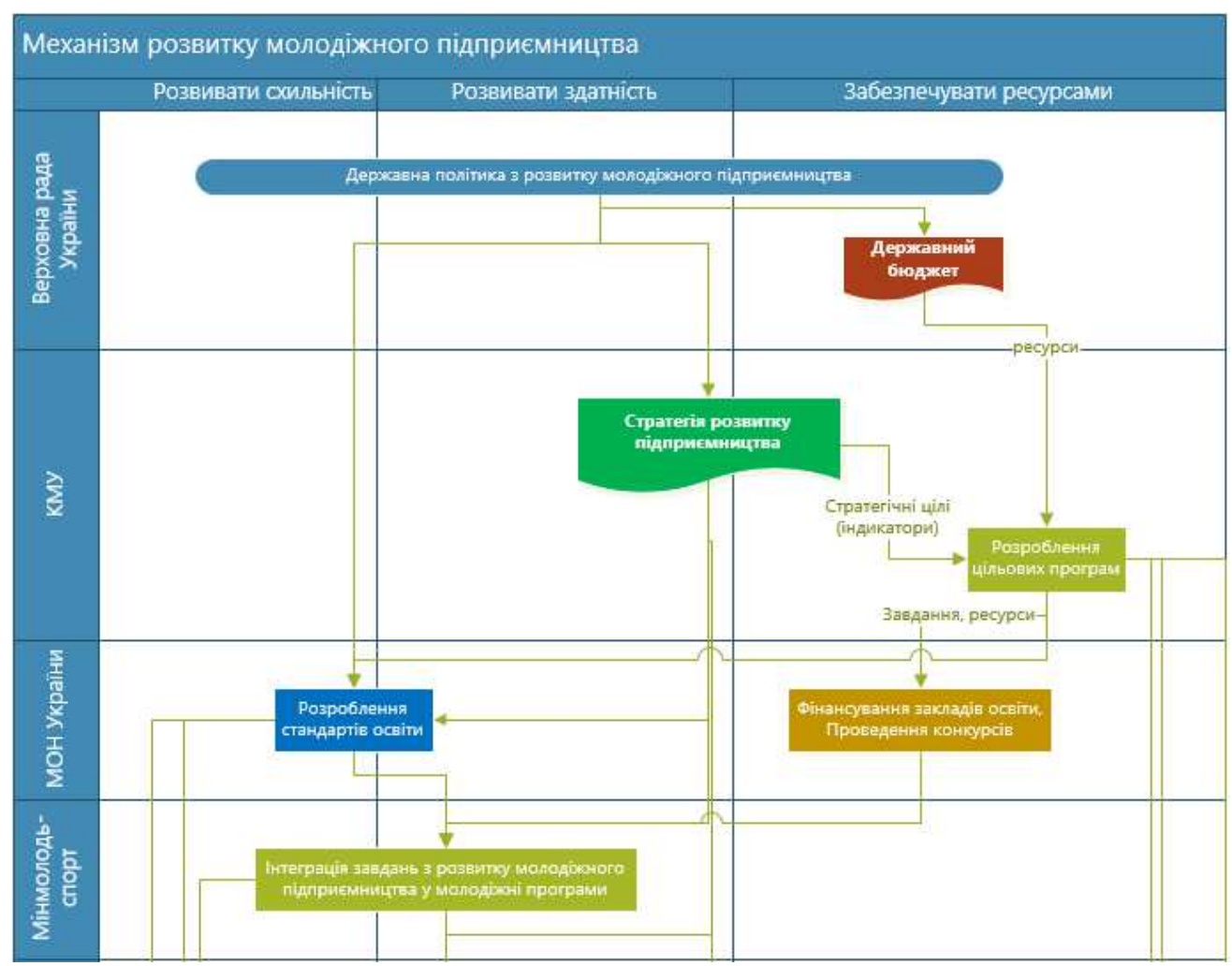

Рис. 3. Механізм розвитку молодіжного підприємництва (частина 2 - регіональний рівень) 


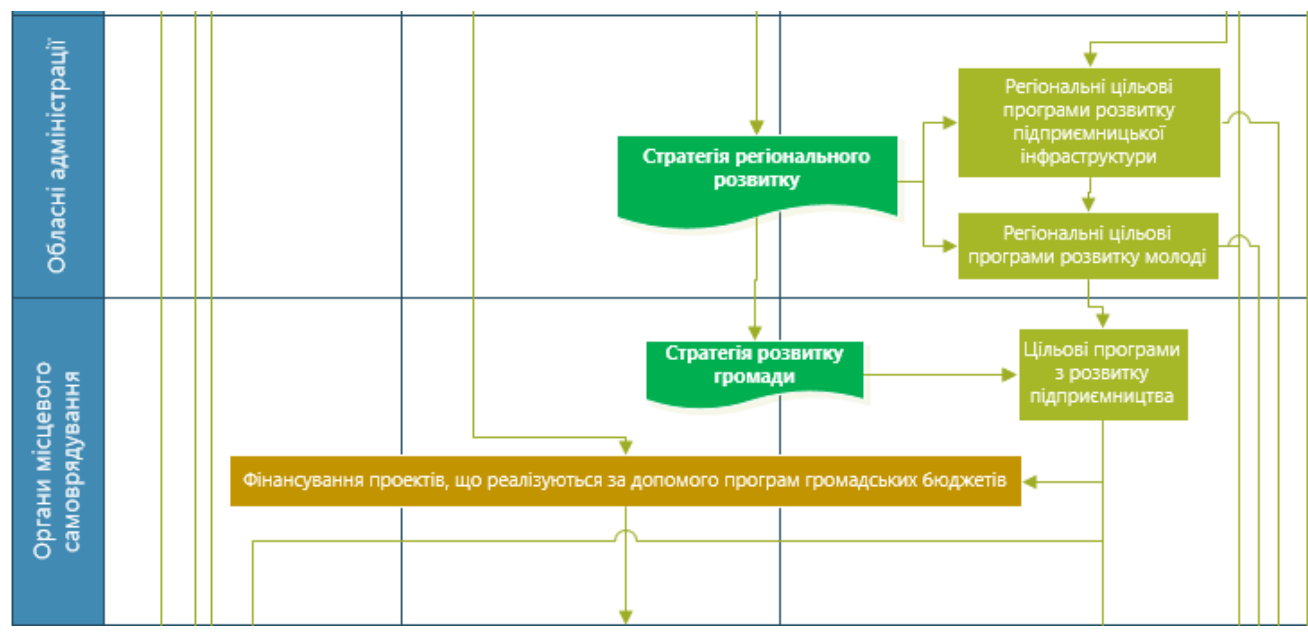

Рис. 4. Механізм розвитку молодіжного підприємництва

(частина 3 - освітня підсистема)

Особливим елементом цієї підсистеми механізму є створення академічних бізнес-інкубаторів, які дадуть змогу не тільки розвивати підприємницькі здатності молоді, а й надавати ресурсні можливості для новостворених підприємницьких структур. В Україні така практика тільки розпочинається. Яскравим прикладом $€$ мережа академічних бізнес-інкубаторів YEP, яка підтримується Міністерством освіти і науки України. У структуру мережі на сьогодні вже входить до десятка університетів.

Останньою складовою механізму, без якого він був би не повноцінним, є мережа суб'єктів, які зацікавлені у розвитку молодіжного підприємництва на рівні організацій та їх об'єднань (див. рис. 5).

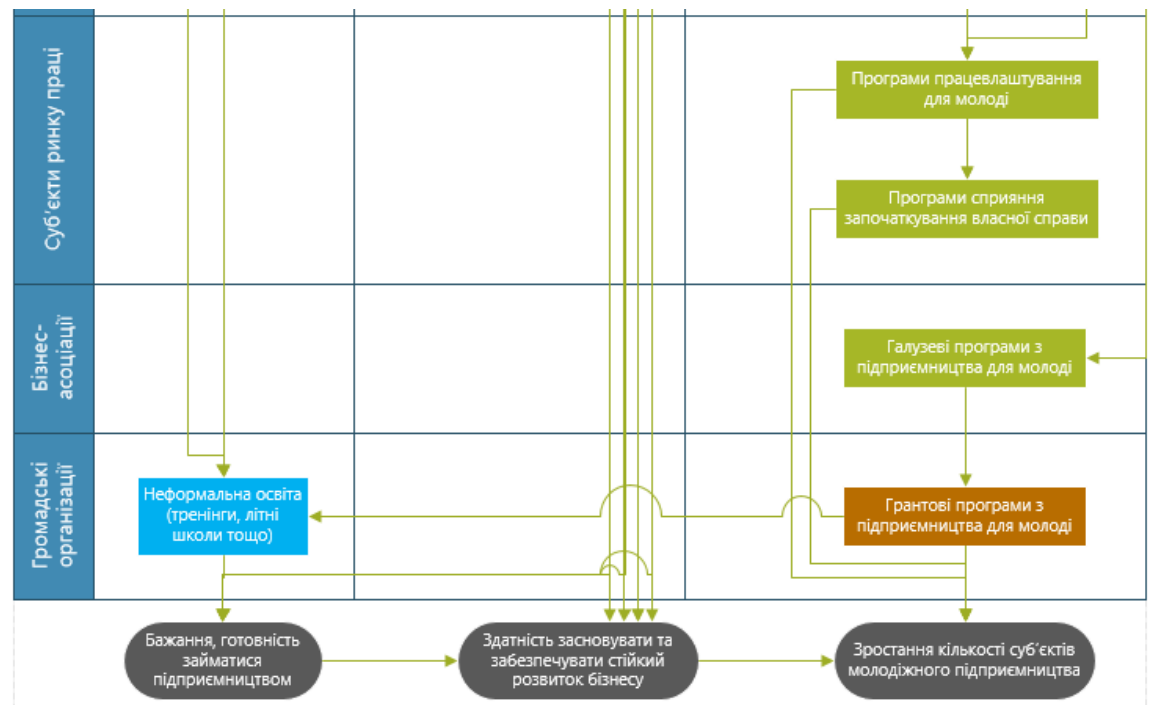

Рис. 5. Механізм розвитку молодіжного підприємництва (частина 4 - інфраструктурна підсистема) 
До таких організацій належать: кадрові агенції, які зацікавлені у якісній пропозиції на ринку праці; центри зайнятості, що мають на меті зменшення обсягів молодіжного безробіття; бізнес-асоціації, що розвивають певні сфери діяльності; громадські організації, серед статутних завдань яких $є$ підтримка молодіжного бізнесу.

Важливим елементом цього механізму є можливості участі молоді у грантових програмах, спрямованих на розвиток малого бізнесу, насамперед у сфері креативних індустрій та соціального підприємництва.

Висновки. Таким чином, механізм розвитку молодіжного підприємництва $є$ складною системою, що охоплює багато елементів, що пов'язані між собою спільними цілями, завданнями, проектами та функціями. I від якості цих системоутворюючих зв'язків залежить ефективність функціонування цієї системи.

В Україні створено достатньо інституційних передумов для розвитку молодіжного підприємництва. Проте, щоб механізм виконував поставлені на нього завдання, потрібно, щоб усі підсистеми працювали як єдине ціле, що дасть змогу для самореалізації молоді і сформує стійкий довгостроковий потенціал розвитку країни.

1. Гросул В. А., Дядюк М. А., Зубков С. А., Сучасний досвід, проблеми та перспективи розвитку молодіжного підприємництва в Україні. URL: http://elib.hduht.edu.ua/jspui/bitstream/123456789/2768/1. (дата звернення: 15.03.2019). 2. Integration Definition For Function Modeling (IDEF0). Draft Federal Information Processing Standards Publication 183, 1993 December 21. 3. Стратегія розвитку малого і середнього підприємництва в Україні на період до 2020 року : розпорядження Кабінету Міністрів України від 24.05. 2017 р. № 504-p. URL: ttps://zakon2.rada.gov.ua/laws/show/504-2017-р (дата звернення: 15.03.2019).

\section{REFERENCES:}

1. Hrosul V. A., Diadiuk M. A., Zubkov S. A., Suchasnyi dosvid, problemy ta perspektyvy rozvytku molodizhnoho pidpryiemnytstva $v$ Ukraini. URL: http://elib.hduht.edu.ua/jspui/bitstream/123456789/2768/1. (data zvernennia: 15.03.2019). 2. Integration Definition For Function Modeling (IDEF0). Draft Federal Information Processing Standards Publication 183, 1993 December 21. 3. Stratehiia rozvytku maloho i serednoho pidpryiemnytstva $v$ Ukraini na period do 2020 roku : rozporiadzhennia Kabinetu Ministriv Ukrainy vid 24.05. 2017 r. № 504-r. URL: ttps://zakon2.rada.gov.ua/laws/show/504-2017-r (data zvernennia: 15.03.2019). 
Kostiukevych A. M., Candidate of Economics (Ph.D.), Kostiukevych R. M., Candidate of Economics (Ph.D.), Associate Professor (National University of Water and Environmental Engineering, Rivne)

\section{SCIENTIFIC AND METHODOLOGICAL APPROACHES TO THE DEVELOPMENT OF YOUTH ENTREPRENEURSHIP SUPPORT MECHANISM IN UKRAINE}

The need to develop a mechanism for supporting youth entrepreneurship in Ukraine has been proved. The conceptual model of the mechanism of youth entrepreneurship development based on the SADT methodology, which analyzes the functions performed by the system, describes the specifications of the requirements and functions of the projected system and designed the systems. Keywords: entrepreneurship, youth entrepreneurship, mechanism of entrepreneurship support, SADT-methodology.

Костюкевич А. Н., К.э.н., Костюкевич Р. Н., к.э.Н., доцент (Национальный университет водного хозяйства и природопользования, г. Ровно)

НАУЧНО-МЕТОДИЧЕСКИЕ ПОДХОДЫ К РАЗРАБОТКЕ МЕХАНИЗМА ПОДДЕРЖКИ МОЛОДЕЖНОГО ПРЕДПРИНИМАТЕЛЬСТВА В УКРАИНЕ

Доказано потребность разработки механизма поддержки молодежного предпринимательства в Украине. Усовершенствована концептуальная модель механизма развития молодежного предпринимательства, основанная на SADT-методологии, с помощью которой анализируются функции, которые выполняет система, описываются спецификации требований и функций проектируемой системы и проектируются системы.

Ключевые слова: предпринимательство, молодежное предпринимательство, механизм поддержки предпринимательства, SADTметодология. 